\title{
Test yourself: cutaneous mass on the thigh
}

\section{Lucas Savaris Linhares $^{1} \cdot$ André Vaz $^{1} \cdot$ Cesar Rodrigo Trippia ${ }^{1} \cdot$ Camila Pietroski Reifegerste $^{2}$}

Published online: 28 November 2019

(C) ISS 2019

\section{Discussion}

The skin lesion demonstrated on imaging exams has a hypervascular nature and, in a patient with a history of HIV with irregular treatment, the hypotheses of Kaposi's sarcoma and bacillary angiomatosis should be considered. The presence of proliferation of spindle-shaped cells and erythrocytefilled cleft-like vascular structures on histopathology, CD34+ (vascular endothelium marker), and D2-40+ (lymphatic endothelium marker) on immunohistochemistry defines the diagnosis of Kaposi's sarcoma.

Kaposi's sarcoma is an angioproliferative neoplasm that can affect multiple systems, such as the skin, mucosa, lymph nodes, gastrointestinal tract, lungs, liver, and spleen [1]. It was first described in 1872 by Moritz Kaposi and, until 1980, was considered a rare condition, but after the onset of the HIV epidemic, its incidence increased and was considered an AIDS-defining disease [2]. The epidemic (or AIDSassociated) form is related to human herpes virus type 8 infection and immunosuppression (mainly by the reduction in CD4 lymphocyte count, especially below 150-200 cells/ $\mathrm{mm}^{3}$ ) and manifests as red, violet, or brown nodular cutaneous lesions that can ulcerate or invade adjacent structures [2-4].

Imaging evaluation of skin lesions may be useful for detecting local invasion and adenopathy. At ultrasound, Kaposi's sarcoma cutaneous lesions are usually multilobulated (with well or poorly delimited margins), hypoechoic and, when related to HIV, intensely vascularized

The case presentation can be found at doi: 10.1007/s00256-019-03349-z

André Vaz

andrevaz7@gmail.com

1 Radiology Department, Nossa Senhora das Gracas Hospital, Rua Alcides Munhoz 433, Curitiba, Parana 80810-040, Brazil

2 Radiology Department, Sao Vicente Hospital, Avenida Vicente Machado 401, Curitiba, Parana 80420-010, Brazil by Doppler [5]. At MRI, lesions often have hyperintense signal in fluid-sensitive sequences (T2 WI and STIR) and avid contrast enhancement [6].

The definitive diagnosis of Kaposi's sarcoma is confirmed by pathology, usually obtained by patch skin biopsy $[1,7]$. Kaposi's sarcoma is histologically characterized by proliferation of spindle-shaped cells, erythrocyte-filled slit or cleft-like vascular spaces, and chronic inflammatory cell infiltrates $[4$, $7,8]$. Immunohistochemistry can detect expression of endothelial cell (vascular or lymphatic) and smooth muscle markers [8]. The main differential diagnosis is bacillary angiomatosis, a pseudoneoplastic infection that can also occur in patients with HIV and is caused by the rickettsia-like Rochalimaea quinmna $[1,8,9]$. As in Kaposi's sarcoma, bacillary angiomatosis also leads to angiomatous skin lesions; however, the latter tends to present more circumscribed and tender lesions with peripheral erythema and much more frequent bone involvement, whereas Kaposi's sarcoma has less defined and painless lesions without peripheral erythema and less frequent bone involvement $[1,9]$. Both can spread and affect lymph nodes, lungs, gastrointestinal tract, liver, and spleen $[2,9]$. Histologically, bacillary angiomatosis is characterized by polygonal endothelial cells accompanied by neutrophils, neutrophilic cellular debris, and granular material of bacterial nature [7-9].

In summary, the differential diagnosis of hypervascularized skin lesions in patients with HIV includes Kaposi's sarcoma and bacillary angiomatosis. Differentiation between such conditions requires biopsy and detection of proliferation of spindle-shaped cells characterizes Kaposi’s sarcoma.

\section{Take-home message}

Angiomatous and hypervascularized cutaneous lesions in HIV patients may be caused by Kaposi's sarcoma and bacillary angiomatosis and the definitive diagnosis usually requires sampling for histological analysis. 


\section{Compliance with ethical standards}

Conflict of interest The authors declare that they have no competing interests.

\section{References}

1. Wyatt SH, Fishman EK. CT/MRI of musculoskeletal complications of AIDS. Skelet Radiol. 1995;24(7):481-8.

2. Restrepo CS, Martínez S, Lemos JA, Carrillo JA, Lemos DF, Ojeda $\mathrm{P}$, et al. Imaging manifestations of Kaposi sarcoma. Radiographics. 2006;26(4):1169-85.

3. Antman K, Chang Y. Kaposi's sarcoma. N Engl J Med. 2000;342(14):1027-38.

4. Caponetti G, Dezube BJ, Restrepo CS, Pantanowitz L. Kaposi sarcoma of the musculoskeletal system: a review of 66 patients. Cancer: Interdisciplinary International Journal of the American Cancer Society. 2007;109(6):1040-52.
5. Solivetti FM, Elia F, Latini A, Cota C, Cordiali-Fei P, Di Carlo A. AIDS-Kaposi sarcoma and classic Kaposi sarcoma: are different ultrasound patterns related to different variants? J Exp Clin Cancer Res. 2011;30(1):40.

6. João P, Cabral P, Penha D, Rosado E, Nogueira D. Kaposi sarcoma presenting as a limb mass. Radiological Case Database: EURORAD; 2013.

7. Thanos L, Mylona S, Kalioras V, Pomoni M, Batakis N. Osseous Kaposi sarcoma in an HIV-positive patient. Skelet Radiol. 2004;33(4):241-3.

8. Vinay K, Abul KA, Jon CA, editors. Robbins and Cotran pathologic basis of disease. 9nd ed. Philadelphia: Elsevier; 2015.

9. Moore EH, Russell LA, Klein JS, White CS, McGuinness G, Davis LG, et al. Bacillary angiomatosis in patients with AIDS: multiorgan imaging findings. Radiology. 1995;197(1):67-72.

Publisher's note Springer Nature remains neutral with regard to jurisdictional claims in published maps and institutional affiliations. 